\title{
Impact of cadmium on young plants of Populus euphratica and $P . \times$ canescens, two poplar species that differ in stress tolerance
}

\author{
A. Polle • T. Klein • C. Kettner
}

Received: 23 June 2011/Accepted: 12 December 2011/Published online: 27 December 2011

(C) The Author(s) 2011. This article is published with open access at Springerlink.com

\begin{abstract}
Populus euphratica is a salt tolerant species, and Populus $\times$ canescens is a salt sensitive species. Because stress tolerance is mediated by an array of overlapping defense mechanisms, we hypothesized that $P$. euphratica would confer co-tolerance to heavy metal stress. To test this hypothesis, both poplar species were exposed to $50 \mu \mathrm{M} \mathrm{Cd}$ for $24 \mathrm{~h}$ in hydroponic solutions. For the analyses of stress symptoms in roots and leaves, we used nutrient element concentrations and transcriptional responses of 28 stress- and defenserelated genes. The roots showed strong Cd accumulation, but less in $P$. euphratica than in $P . \times$ canescens. In contrast, the leaves of $P$. euphratica accumulated 10-times more $\mathrm{Cd}$ than those of $P . \times$ canescens. Cd-stressed leaves of $P$. euphratica displayed water loss and wilting. Both species revealed contrasting transcriptional responses of defense genes to $\mathrm{Cd}$ stress. In $P$. euphratica, glutathione reductase, dehydroascorbate reductase and glutathione $S$-transferases of the theta and tau classes showed increases in transcript levels in response to $\mathrm{Cd}$, pointing to oxidative stress and a strong activation of detoxification mechanisms. In contrast, in $P . \times$ canescens transcript levels of genes involved in signaling, activation of, and protection from drought stress were significantly increased including glutathione $S$-transferases of the phi class (early response to dehydration). Our data show that $P$. euphratica salt tolerance does not confer $\mathrm{Cd}$ tolerance and suggest that failure to activate early protection contributed to higher $\mathrm{Cd}$ sensitivity in $P$. euphratica than in P. $\times$ canescens.
\end{abstract}

Keywords Drought - Glutathione $S$-transferase $\cdot$ Heavy metal stress · Salinity · Transcript profiling · Transcription factor

\footnotetext{
A. Polle - C. Kettner

Department of Forest Botany and Tree Physiology, Büsgen-Institut,

Georg-August Universität Göttingen, Büsgenweg 2, 37077 Göttingen, Germany

A. Polle $(\bowtie) \cdot T$. Klein

Laboratory for Radio-Isotopes, Georg-August Universität Göttingen,

Büsgenweg 2, 37077 Göttingen, Germany

e-mail: apolle@gwdg.de
} 


\section{Introduction}

Cadmium (Cd) exerts negative effects on growth of most plant species, even at low concentrations (Sanita di Toppi and Gabbrielli 1999; Schützendübel and Polle 2002). Because it has high affinity for thiol groups, Cd affects the cellular sulfhydryl homeostasis by inhibition of SH-containing redox regulated enzymes (Schützendübel et al. 2001; Sharma and Dietz 2009). As a consequence, this may lead to oxidative stress (Markovska et al. 2009; Rodriguez-Serrano et al. 2009). In Populus $\times$ canescens, short- and long-term exposure to Cd caused significant $\mathrm{H}_{2} \mathrm{O}_{2}$ accumulation as well as stimulation of antioxidative systems (Schützendübel et al. 2002; He et al. 2011). This activation contributes to amelioration of Cd-induced stress symptoms (Gratao et al. 2005). The performance of poplars under Cd stress is of importance because of the potential of fast growing tree species for use in soil reclamation (Robinson et al. 2000). Many poplar species are adapted to riparian ecosystems (Dickmann and Kuzovkina 2008). Therefore, their vulnerability to sudden spills of polluted water is of particular interest, for example after hazardous discharges into rivers from industrial hubs and smelting plants or by overflow of mining drainages (Galiulin et al. 2001).

Previous studies reveal that Populus euphratica is highly salt tolerant and can cope with $\mathrm{NaCl}$ concentrations above $300 \mathrm{mM}$ for extended periods of time (Chen and Polle 2010). It is a poplar species acclimated to dry hot areas, grown along river banks in Asia. In contrast, $P . \times$ canescens is relatively salt sensitive, showing growth reductions at $\mathrm{NaCl}$ concentrations of about $100 \mathrm{mM}$ (Chen and Polle 2010). Many examples show that plants that can tolerate a particular stress factor also exhibit co-tolerance to other stresses (Pastori and Foyer 2002). Janz et al. (2010) showed an innate up-regulation of defense pathways in P. euphratica. Activated stress protection measures may then counteract multiple environmental constraints (Singh et al. 2010). For example, prior exposure to low salinity stress enhanced defenses against abiotic stress and subsequently rendered treated Arabidopsis thaliana plants more Cd tolerant than untreated plants (Xu et al. 2010). Glutathione (GSH) is a crucial compound mediating Cd tolerance (Wójcik and Tuikendorf 2011). The activation of glutathione-related genes, in particular glutathione $S$-transferases (GSTs), has frequently been observed in response to Cd exposure (Suzuki et al. 2001). In poplars, Cd exposure also affected glutathione (GSH) and activated GST activities (Schützendübel et al. 2002; Nikolic et al. 2008; Kieffer et al. 2009). Heavy metal stimulation of general stress responses was found to partially overlap with responses of poplars exposed to salinity (Nikolic et al. 2008; Ottow et al. 2005).

Since both Cd and salt enter the plant via the root system and activate, at least, partially common defence responses, we hypothesized that the salt tolerant species $P$. euphratica, with its innate upregulation of defence pathways (Janz et al. 2010) may also be more tolerant to Cd stress than the salt sensitive species $P . \times$ canescens. To test this hypothesis, the performance of both poplar species was investigated under short-term Cd stress. As a hallmark of Cd toxicity, the water balance was studied. Because signaling and glutathione-related defenses belong to the suite of stress markers, a macroarray containing oxidative stress- and GSH-related genes was constructed and applied to investigate the molecular reactions in roots and leaves of both species.

\section{Materials and methods}

Plant cultivation, $\mathrm{Cd}$ exposure and harvest

Plantlets of $P$. euphratica and $P . \times$ canescens (a hybrid of P. tremula $\times$ P. alba) were multiplied by micro-propagation $\left(\mathrm{KNO}_{3} 24.7 \mathrm{mM},\left(\mathrm{NH}_{4}\right) \mathrm{H}_{2} \mathrm{PO}_{4} 2.61 \mathrm{mM}, \mathrm{MgSO}_{4} \cdot 7 \mathrm{H}_{2} \mathrm{O}\right.$ 
$1.62 \mathrm{mM}, \mathrm{CaCl}_{2} \cdot 2 \mathrm{H}_{2} \mathrm{O} 1.36 \mathrm{mM}, \mathrm{MnSO}_{4} \cdot \mathrm{H}_{2} \mathrm{O} 5.9 \mu \mathrm{M}, \mathrm{H}_{3} \mathrm{BO}_{3} 4.9 \mu \mathrm{M}, \mathrm{ZnSO}_{4} \cdot 7 \mathrm{H}_{2} \mathrm{O}$ $1.0 \mu \mathrm{M}$, KI $0.5 \mu \mathrm{M}, \mathrm{Na}_{2} \mathrm{MoO}_{4} \cdot 2 \mathrm{H}_{2} \mathrm{O} 0.1 \mu \mathrm{M}, \mathrm{CoCl}_{2} \cdot 6 \mathrm{H}_{2} \mathrm{O} 0.1 \mu \mathrm{M}, \mathrm{CuSO}_{4} \cdot 5 \mathrm{H}_{2} \mathrm{O} 0.1 \mu \mathrm{M}$, nicotinic acid $4.061 \mu \mathrm{M}$, pyridoxine- $\mathrm{HCl} 2.4 \mu \mathrm{M}$, thiamine- $\mathrm{HCl} 0.297 \mu \mathrm{M}$, $\mathrm{C}_{10} \mathrm{H}_{12} \mathrm{FeN}_{2} \mathrm{NaO}_{8} 10 \mu \mathrm{M}$, inosit $555 \mu \mathrm{M}$, glycine $26 \mu \mathrm{M}$, sucrose $25.0 \mathrm{~g} \mathrm{l}^{-1}$, gelrite $2.8 \mathrm{~g} \mathrm{l}^{-1}, \mathrm{pH}$ 5.7). They were then transferred to aerated Long-Ashton medium for hydroponic cultivation $\left(\mathrm{Ca}\left(\mathrm{NO}_{3}\right)_{2} \cdot 4 \mathrm{H}_{2} \mathrm{O} \quad 0.9 \mathrm{mM}, \mathrm{KH}_{2} \mathrm{PO}_{4} 0.6 \mathrm{mM}, \mathrm{MgSO}_{4} \cdot 7 \mathrm{H}_{2} \mathrm{O}\right.$ $0.3 \mathrm{mM}, \mathrm{KNO}_{3} 0.2 \mathrm{mM}, \mathrm{K}_{2} \mathrm{HPO}_{4} 0.031 \mathrm{mM}, \mathrm{H}_{3} \mathrm{BO}_{3} 10 \mu \mathrm{M}, \mathrm{Na}_{2} \mathrm{MoO}_{4} \cdot 2 \mathrm{H}_{2} \mathrm{O} 7 \mu \mathrm{M}$, $\mathrm{MnSO}_{4} \cdot 4 \mathrm{H}_{2} \mathrm{O} 2 \mu \mathrm{M}, \mathrm{H}_{3} \mathrm{BO}_{4} 0.2 \mu \mathrm{M}, \mathrm{ZnSO}_{4} \cdot 7 \mathrm{H}_{2} \mathrm{O} \quad 0.2 \mu \mathrm{M}, \mathrm{CuSO}_{4} \cdot 5 \mathrm{H}_{2} \mathrm{O} \quad 0.13 \mu \mathrm{M}$, $\mathrm{CoSO}_{4} \cdot 7 \mathrm{H}_{2} \mathrm{O} 0.04 \mu \mathrm{M}, \mathrm{C}_{10} \mathrm{H}_{12} \mathrm{FeN}_{2} \mathrm{NaO}_{8} 10 \mu \mathrm{M}, \mathrm{pH}$ 5.5). They were grown in a grow room at $22^{\circ} \mathrm{C}, 60 \%$ air humidity, and $18 \mathrm{~h}$ of light per day $\left(200 \mu \mathrm{mol}\right.$ photons $\mathrm{m}^{-2} \mathrm{~s}^{-1}$ of photosynthetic active radiation). Approximately six-weeks-old plants were exposed to $50 \mu \mathrm{M} \mathrm{CdSO}_{4}$ in the nutrient solution. After $24 \mathrm{~h}$, the plants were separated into leaves, stem and roots. Aliquots of roots and leaves were immediately shock-frozen in liquid nitrogen. The residual material was weighed and dried for 7 days at $60^{\circ} \mathrm{C}$. The relative water loss was determined using the following equation:

$$
100-[(\text { fresh mass }- \text { dry mass }) \times 100 / \text { fresh mass }] .
$$

Nutrient element determination

The aliquots of dry roots and leaves were milled and then pressure-extracted in $\mathrm{HNO}_{3}$. The extracts were for nutrient element analyses by induced coupled plasma atomic emission spectroscopy (SPECTRO CIRO CCD, GmbH \& Co KG, Kleve, Germany, Heinrichs et al. 1986).

\section{Molecular analyses}

RNA was extracted after the method of Chang et al. (1993), purified with the DNA-free ${ }^{\mathrm{TM}}$ reagent kit (Ambion, Kaufungen, Germany), labeled with SuperScript III cDNA (Invitrogen, Life Technologies GmbH, Darmstadt, Germany) using $\left[\alpha-{ }^{32} \mathrm{P}\right] \mathrm{dCTP}$ (Amersham Biosciences, Freiburg, Germany) and purified with the QIAquick nucleotide removal kit (Qiagen GmbH, Hilden Germany). The activity was determined by counting the Cerenkov radiation. The labeled samples $(6 \mathrm{kBq} / \mathrm{ml})$ were used as probes for dot-blot analysis on macroarrays.

Using the method described by Ottow et al. (2005), cDNAs of 31 selected genes of $P$. euphratica and one blank (Brosché et al. 2005) were printed in three replicates on nylon membranes (Hyobond N1, Amersham Bioscience, Freiburg, German). The following cDNAs were spotted [listed by Genbank accession number (abbreviation and name of best BLASTn match with A. thaliana)]: AJ768404 (NADPH oxidase, heavy chain), AJ768299 (ATPase, calcium-transporting ATPase 4, plasma membrane-type), AJ771884 (ERF, ethylene response factor, subfamily B-3 of ERF/AP2 transcription factor family), AJ778500 (HB-7, putative homeodomain leucine zipper transcription factor), AJ770753 (CML, calcium binding calmodulin-like protein), AJ768233 (DHAR, dehydroascorbate reductase), AJ778201 (GR, glutathione reductase), AJ767703, AJ778382 (GPX1, GPX2 glutathione peroxidases), AJ776883 (ADH2, zinc containing alcohol dehydrogenase, GroESlike), AJ769438, AJ768435 (ADH1, ADH3, alcohol dehydrogenase class III, glutathione dependent formaldehyde dehydrogenase), AJ779443, AJ770693, AJ771208 (MT1, MT2, MT3 [metallothionein-like proteins]), AJ780543 (glutathione $S$-conjugate transporting ATPase), AJ770330 (multidrug resistance-associated protein 5), AJ771717 (calcium- 
transporting ATPase 1, plasma membrane-type), AJ772010 (ATP-binding cassette, subfamily F, member 2), AJ771590 (calcium-dependent protein kinase, isoform 11, CDPK 11) and glutathione $S$-transferases from different classes: AJ779726 (GST1, phi), AJ768858 (GST2, pi), AJ769448 (GST3, theta), AJ780471 (GST4, zeta), AJ773536 (GST5, theta), AJ775038 (GST6, theta), AJ773476 (GST7, tau) and AJ775724 (GST8, tau). Loading controls were performed by hybridizing against the transformation vector. Dot blots were hybridized with labeled samples overnight at $42^{\circ} \mathrm{C}$ (UVP Laboratory Products, HB 100 Hybridiser, Cambridge, England) in Ultrahyb buffer (Ambion, Kaufungen, Germany) and washed twice in saline sodium citrate before exposure on a Fuji imaging plate (BAS 1500, Fujifilm, Raytest Isotopenmeßgeräte GmbH, Straubenhardt, Germany). After 6 h, the spots were analyzed with a phosphor imager using AIDA software (Image Analyzer, Raytest Isotopenmeßgeräte $\mathrm{GmbH}$, Straubenhardt, Germany). Each cDNA was spotted three times per filter. Four independent biological replicates were analyzed. Signals were expressed relative to tubulin (Genbank accession number: AJ775509) as the house keeping gene. Actin (AJ775312) and 18SrRNA (AJ775618) were also present on the filter but showed significant changes in response to $\mathrm{Cd}$ and were therefore not used as reference genes.

Statistical analysis

Data for biomass, cadmium and water content are the means of $n=6( \pm \mathrm{SE})$. Data for transcript levels are the means of $n=4$ biological replicates $( \pm \mathrm{SE})$, with each replicate being the mean of three technical replicates. Data were analyzed with Statgraphics (STN, St. Louis) using ANOVA or MANOVA. The means were considered to differ significantly if $P \leq 0.05$. Stars indicate statistical significance levels: $* P \leq 0.05$, ** $P \leq 0.01$, and $* * * P \leq 0.001$.

\section{Results and discussion}

Higher Cd transport and sensitivity in $P$. euphratica than in $P . \times$ canescens

Cd did not cause any significant changes in the relative water content of $P . \times$ canescens in either the leaves or roots (Fig. 1a). In contrast, the $P$. euphratica leaves displayed severe wilting (not shown), due to massive dehydration in response to Cd exposure (Fig. 1a). No significant changes in the water content of the roots were found (Fig. 1a).

The roots of both poplar species accumulated high concentrations of $\mathrm{Cd}$, but $P$. euphratica accumulated less than $P . \times$ canescens (Fig. 1b). However, the leaves of $P$. euphratica contained more $\mathrm{Cd}$ than those of $P . \times$ canescens (Fig. 1b). These results show that the transport to the aboveground tissues was higher, and root retention lower, in $P$. euphratica than in $P . \times$ canescens.

The massive disturbance of the water balance in response to $\mathrm{Cd}$ in the leaves of $P$. euphratica indicates that its $\mathrm{Cd}$ sensitivity is higher than that of $P . \times$ canescens. Damage of the photosynthetic apparatus and disruption of water balance are well-known effects of Cd on plants (Rascio et al. 2008). Still, the strong negative effect of $\mathrm{Cd}$ on $P$. euphratica was surprising because the overall $\mathrm{Cd}$ accumulation in the foliage was moderate, just in a range where initial biomass reductions were reported by BahlsbergPahlsson (1989). In contrast, $P . \times$ canescens accumulated about $60-70 \mu \mathrm{g} \mathrm{Cd} \mathrm{g}^{-1} \mathrm{~d}$.wt. without any massive effects on photosynthesis (He et al. 2011), suggesting its higher Cd tolerance. 
Fig. 1 Changes in the water and cadmium contents after $24 \mathrm{~h}$ of $\mathrm{Cd}$ exposure relative to the controls in $P . \times$ canescens (white bars) and in P. euphratica (black bars). The water content of the controls of each species was set as $100 \%$, and the water loss was calculated as described in the "Materials and methods" section. Cd increment is as follows: [Concentration of $\mathrm{Cd}$ (after $24 \mathrm{~h}$ exposure)Concentration of $\mathrm{Cd}$ (controls)]. The Cd concentration of the control leaves was below the detection limit and that of the roots was $2.2 \pm 1.8 \mu \mathrm{g} \mathrm{Cd} \mathrm{g}^{-1}$ d.wt. Data are the means of $\mathrm{n}=6( \pm \mathrm{SE})$. Letters different from "a" indicate significant differences compared to the controls
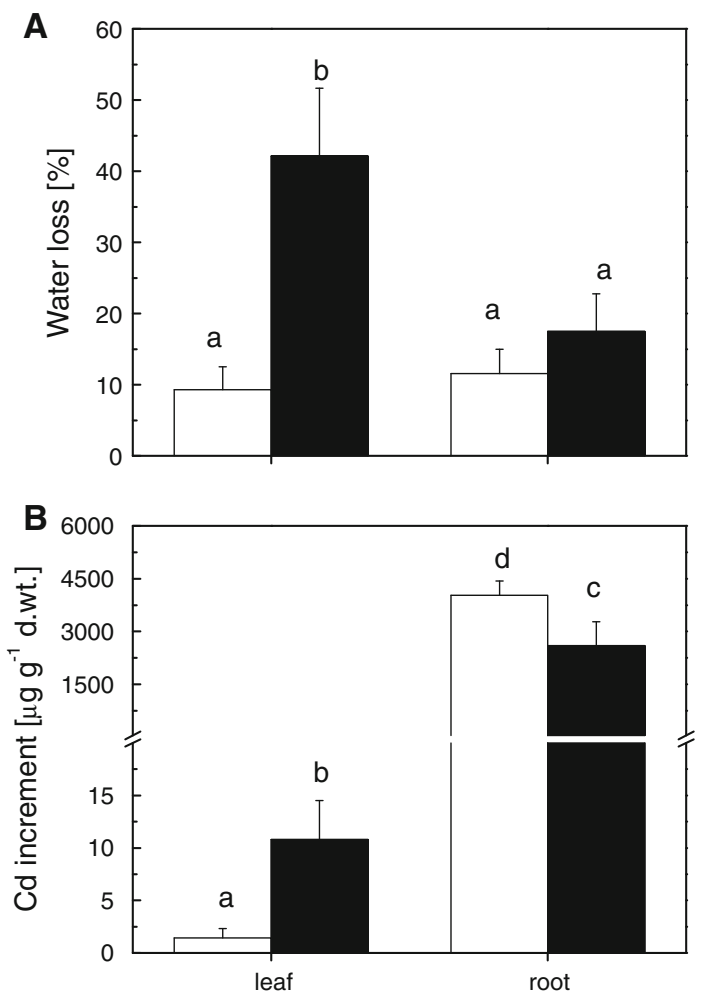

To investigate if exposure to $\mathrm{CdSO}_{4}$ interfered with nutrient uptake, in particular that of calcium or sulfur, major nutrient elements were measured in the roots and leaves. With the exception of iron, which increased in Cd-treated plants of $P . \times$ canescens, no significant changes in any of the nutrients were found in response to $\mathrm{Cd}$ in the roots of any species (Table 1). In contrast, some nutrient elements in the leaves were influenced by $\mathrm{Cd}$ exposure (Table 1). For example, the calcium concentrations in Cd-exposed $P . \times$ canescens leaves decreased, whereas calcium increased in $P$. euphratica leaves. This observation does not suggest that the lower Cd susceptibility of $P . \times$ canescens was caused by greater Ca depletion. In the leaves of $P . \times$ canescens, but not in those of $P$. euphratica, sulfur increased after $\mathrm{CdSO}_{4}$ addition to the nutrient solution (Table 1). Because the leaves of unstressed $P$. euphratica contained higher sulfur concentrations than those of $P . \times$ canescens, it is unlikely that differences in foliar sulfur concentrations were responsible for the observed Cd susceptibility of $P$. euphratica. We exposed the plants to a sudden burden of high $\mathrm{Cd}$, which can occur in rivers after industrial hazards or when rain storms cause spills of smelting plant drainage ponds (Galiulin et al. 2001). Under those conditions, there is insufficient time to allow for acclimation involving morphological adaptation of the plant tissues. Therefore, it is possible that the reaction of mature trees may differ, especially when they are exposed to sub-lethal chronic Cd concentrations.

Cd induces different gene expression patterns in $P$. euphratica and $P . \times$ canescens

A total of 28 genes related to oxidative stress and detoxification were selected from a previously established expressed sequence tag (EST) collection of $P$. euphratica 


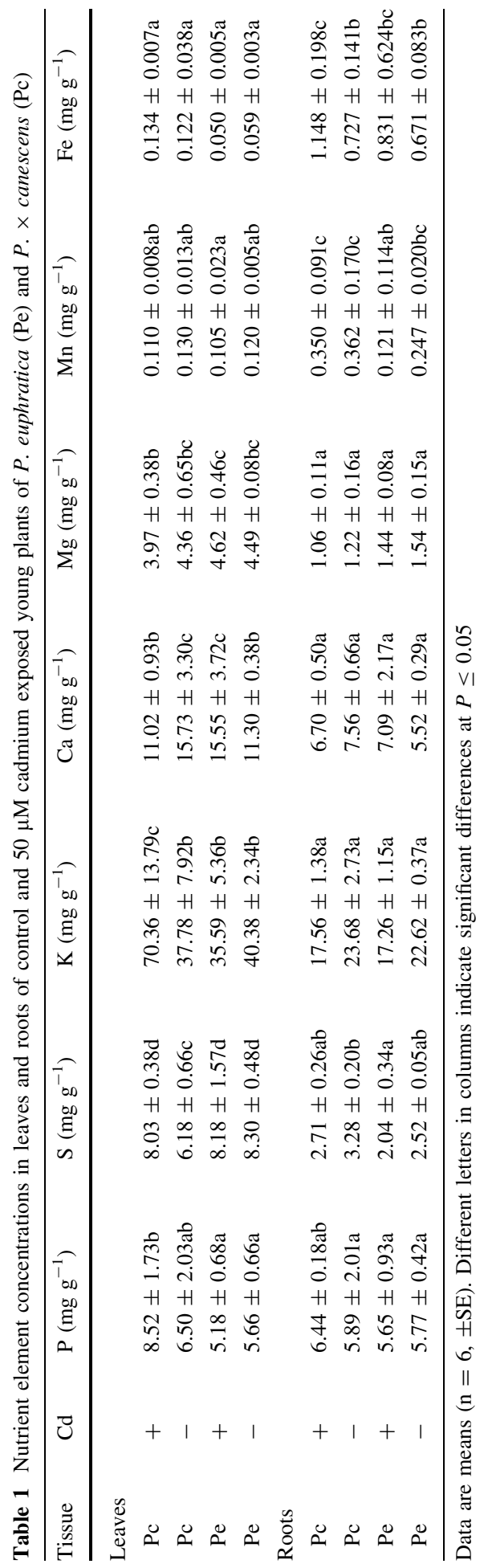


(Brosché et al. 2005). Among these genes, five genes (a putative glutathione $S$-conjugate transporting ATPase, a calcium-transporting ATPase 1, a calcium-dependent protein kinase, a putative $\mathrm{ABC}$ transporter, and a multidrug resistance-associated protein 5) were apparently not expressed under our conditions because their transcript abundances were indistinguishable from background levels (not shown). Three genes (an ADH and two MTs) were leaf-specific because their signals were not found in the roots of either P. euphratica or P. $\times$ canescens (Fig. 2a, b).

The relative transcript abundances of 14 genes were significantly increased in the leaves of Cd-exposed $P . \times$ canescens trees (Fig. 2a). These genes included two stress-responsive transcription factors: $H B-7$, which is regulated in an ABA-dependent manner and may act in a signal transduction pathway mediating drought responses (Olsson et al. 2004) and a putative ethylene response factor (ERF) (Libault et al. 2007). Furthermore, increases were found in the relative transcript levels of a putative calmodulin-regulated calcium-transporting ATPase that is responsive to osmotic stress (Boursiac et al. 2010) and a calcium

Fig. 2 Changes in transcript abundance after $24 \mathrm{~h}$ of $\mathrm{Cd}$ exposure relative to the controls (S/C) in P. $\times$ canescens (white bars) and in P. euphratica (black bars). Data are the means of $\mathrm{n}=4( \pm \mathrm{SE})$. The dotted line indicates the ratio of $\mathrm{S} / \mathrm{C}=1$, i.e., equal transcript abundances in unstressed controls and Cdtreated plants. Stars above the bars indicate significant changes relative to unstressed controls, with the following statistical significance: $* P<0.05$, $* * P<0.01$ or $* * * P<0.001$. Lack of a star indicates no significant change. $N d$ not detected. Abbreviations refer to ESTs shown under "Materials and methods" section

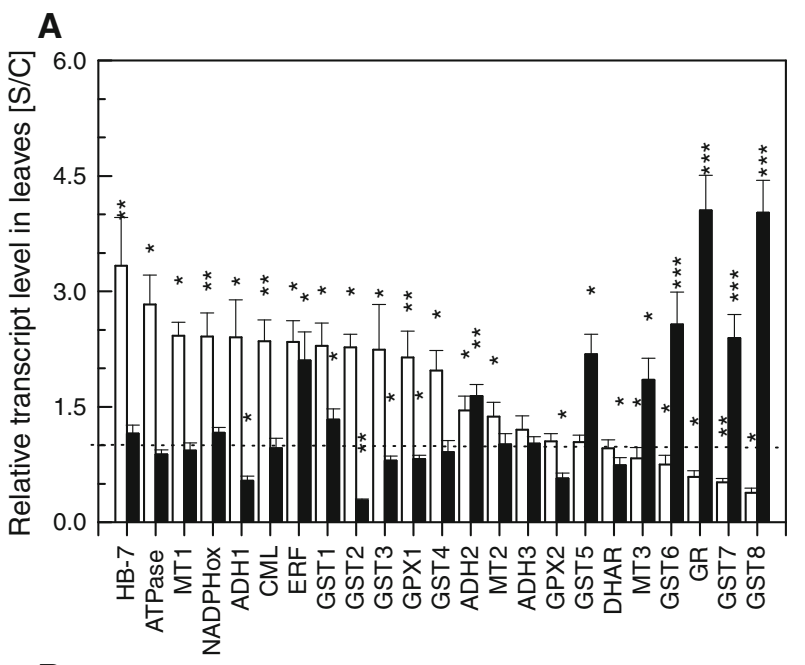

B

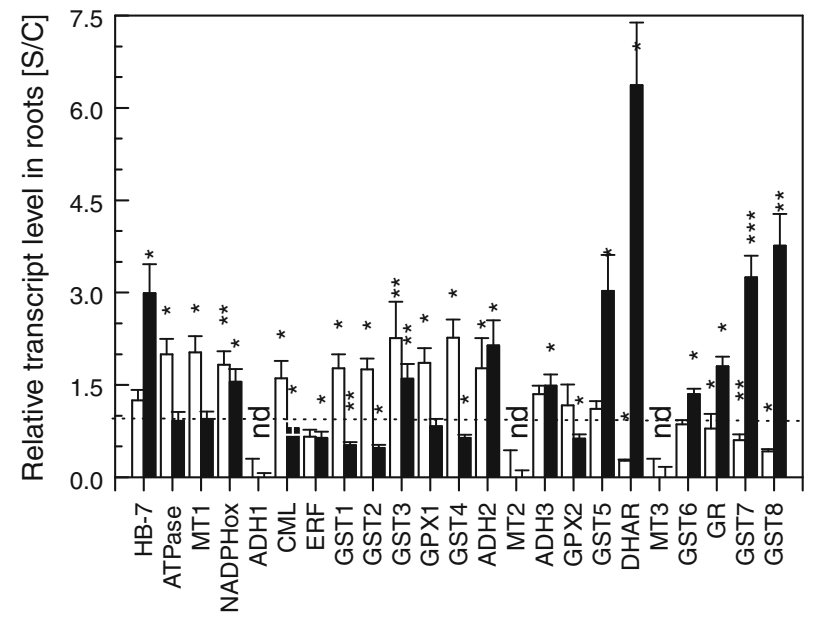


binding calmodulin-like protein (CML) (McCormack et al. 2005). Increases were also found in the relative transcript levels of $A D H \mathrm{~s}$, which are known to play roles in drought tolerance (Polle et al. 2006), probably because of GSH-dependent removal of formaldehyde (Diaz et al. 2003). These observations suggest that $\mathrm{Cd}$ is sensed and results in an up regulation of stress response genes important for protection from osmotic stress in P. $\times$ canescens. In addition, NADPH oxidase, which is responsible for $\mathrm{H}_{2} \mathrm{O}_{2}$ production as well as various GSTs, MTs and glutathione peroxidases (GPX) displayed increased transcript abundances in $P . \times$ canescens (Fig. 2a). These enzymes are important for detoxification processes and maintenance of redox homeostasis (Edwards et al. 2000; Sharma and Dietz 2009).

Notably, the transcript levels of our collection of stress-related genes showed opposing behavior in Cd-exposed leaves of $P$. euphratica (Fig. 2a). With the exception of ERF and an $A D H$, none of the genes stimulated in $P . \times$ canescens were activated by $\mathrm{Cd}$ stress in $P$. euphratica. Whereas, GSTs with decreased relative transcript abundance in P. $\times$ canescens, and glutathione reductase $(G R)$, were enhanced in P. euphratica (Fig. 2a). With few exceptions, the transcript abundances of the same set of stress- and defense-related genes that were increased in the leaves of $P . \times$ canescens were also enhanced in the roots of Cd-exposed $P . \times$ canescens. Notably, these genes were decreased in P. euphratica (Fig. $2 \mathrm{~b}$ ). Similarly, genes that were not induced, or showed decreased transcript abundance in $P . \times$ canescens, were stimulated in P. euphratica roots (Fig. 2b). The strongest increment was found for dehydroascorbate reductase in Cd stressed roots of $P$. euphratica.

Overall, these results show that typical defense and signaling pathways stimulated by $\mathrm{Cd}$ in $P . \times$ canescens were not responsive, or were even suppressed, in $P$. euphratica. This may have contributed to higher sensitivity to $\mathrm{Cd}$ in the latter species. The activation of glutathione reductase and dehydroascorbate reductase suggests a strong oxidative stress in $P$. euphratica. Most genes selected for our analyses have a broad response spectrum, notably including drought and osmotic stress. The lack of responsiveness in P. euphratica may have contributed to failure in activating protective measures and may have resulted in the significant water loss and symptoms of drought stress. Recent biochemical analyses of eucalypt exposed to salt or osmotic stress also suggest segregation of these traits (Cha-um and Kirdmanee 2010).

GSTs are a highly divergent family of proteins, whose functions in vivo are not yet understood (Edwards et al. 2000; Dixon et al. 2009; Lan et al. 2009). Although we can only speculate about the reasons for the differential regulation of the analyzed GST genes in $P . \times$ canescens and $P$. euphratica, we noted that the GSTs with increased transcript abundance in $P$. euphratica belong to the tau and theta classes. These classes have functions in the detoxification of organic hydroperoxides (theta class), or act as hormone responsive ligandins (tau class) (Edwards et al. 2000). In contrast, the GSTs with increased transcript levels in P. $\times$ canescens were-with one exception (AJ769448)-members of the pi, zeta and phi classes. The phi class contains proteins previously called ERD (early response to dehydration), underlining the significance of activation of drought responses as a protection from $\mathrm{Cd}$.

In conclusion, this study shows that $P$. euphratica, a species acclimated to saline and arid conditions (Janz et al. 2010), was even more sensitive to Cd than P. $\times$ canescens. This result was surprising as it is in contrast to our initial hypothesis. One reason for the observed $\mathrm{Cd}$ sensitivity of $P$. euphratica is probably its higher uptake and transport rate of Cd to aboveground tissues. Furthermore, $P . \times$ canescens and $P$. euphratica showed diverging responses of the genes analyzed. In $P . \times$ canescens leaves, the transcript abundance of several genes involved in signaling and activation of stress tolerance mechanisms increased, whereas in $P$. euphratica the main responses were increased in GSTs likely involved in detoxification. 
Apparently, in P. euphratica, activation of broader defense mechanisms failed, and detoxification was insufficient to prevent injury. The observed up-regulation of genes important for drought tolerance in $P . \times$ canescens suggests that these genes are implicated in co-tolerance to $\mathrm{Cd}$. In fact, co-tolerance to drought and $\mathrm{Cd}$ has previously been reported for wheat cultivars (Milone et al. 2003), which supports our conclusion. Furthermore, P. euphratica, despite its occurrence in dry hot areas, is not drought tolerant because it forms a deep rooting system with permanent access to the water table (Chen and Polle 2010). A comparison of different poplar species showed that $P$. euphratica was among the most sensitive to drought (Hukin et al. 2005). Based on the findings of the present study, usage of $P$. euphratica for soil reclamation does not appear advisable. Further long-term studies under field conditions are required before definite recommendations can be made. These studies should preferably be conducted in different environments to test for genotype/environment interactions, as suggested by Sixto et al. (2011).

Acknowledgments We are grateful to the German Science foundation (DFG) for support to Poplar Research Group Germany (FOR496) and to M. Brinker and D. Janz for help with designing the macroarrays.

Open Access This article is distributed under the terms of the Creative Commons Attribution Noncommercial License which permits any noncommercial use, distribution, and reproduction in any medium, provided the original author(s) and source are credited.

\section{References}

Bahlsberg-Pahlsson AM (1989) Toxicity of heavy metals (Zn, Cu, Cd, Pb) to vascular plants. Water Air Soil Pollut 47:287-319

Boursiac Y, Lee SM, Romanowsky SM, Blank RR, Sladek C, Chung WS, Harper JF (2010) Disruption of the vacuolar calcium-ATPases in Arabidopsis results in the activation of a salicylic acid-dependent programmed cell death pathway. Plant Physiol 154:1158-1171

Brosché M, Vinocur B, Alatalo ER, Lamminmäki A, Teichmann T, Ottow EA, Djilianov D, Afif D, Triboulot-Bogeat MB, Altman A, Polle A, Dreyer E, Rudd S, Paulin L, Auvinen P, Kangasjärvi J (2005) Gene expression and metabolite profiling of Populus euphratica growing in the Negev desert. Genome Biol 6:R101

Chang S, Puryear J, Cairney J (1993) A simple and efficient method for isolating RNA from pine trees. Plant Mol Biol Rep 11:113-116

Cha-um S, Kirdmanee C (2010) Effects of water stress induced by sodium chloride and mannitol on proline accumulation, photosynthetic abilities and growth characters of eucalyptus (Eucalyptus camaldulensis Dehnh.). New For 40:349-360

Chen SL, Polle A (2010) Salt tolerance in Populus. Plant Biol 12:317-333

Diaz M, Achkor H, Titarenko E, Martinez MC (2003) The gene encoding glutathione-dependent formaldehyde dehydrogenase/GSNO reductase is responsive to wounding, jasmonic acid and salicylic acid. FEBS Lett 543:136-139

Dickmann DI, Kuzovkina J (2008) Poplars and willows of the world, with emphasis on silviculturally important species. In: Poplars and willows of the world. Chapter 2, Working Paper IPC/9-2, FAO, Rome, Italy, http://www.fao.org/forestry/ipc/69946@158687/en/

Dixon DP, Hawkins T, Hussey PJ, Edwards R (2009) Enzyme activities and subcellular localization of members of the Arabidopsis glutathione transferase superfamily. J Exp Bot 60:1207-1218

Edwards R, Dixon DP, Walbot V (2000) Plant glutathione $S$-transferases: enzymes with multiple functions in sickness and in health. Trends Plant Sci 5:193-198

Galiulin RV, Bashkin VN, Galiulina RR, Birch P (2001) A critical review: protection from pollution by heavy metals-phytoremediation of industrial wastewater. Land Contam Reclam 9:349-357

Gratao PL, Polle A, Lea PJ, Azevedo RA (2005) Making the life of heavy metal-stressed plants a little easier. Func Plant Biol 32:481-494

He J, Qin J, Long LY, Ma YL, Li H, Li K, Jiang XN, Liu TX, Polle A, Liang Z, Luo ZB (2011) Net cadmium flux and accumulation reveal tissue-specific oxidative stress and detoxification in Populus $\times$ canescens. Physiol Plant 143:50-63

Heinrichs H, Brumsack HJ, Loftfield N, König N (1986) Verbessertes Druckaufschlußsystem für biologische und anorganische Materialien. Zeitschr Pflanzenernähr Bodenk 149:350-353 
Hukin D, Cochard H, Dreyer E, Le Thiec D, Bogeat-Triboulot MB (2005) Cavitation vulnerability in roots and shoots: does Populus euphratica Oliv., a poplar from arid areas of Central Asia, differ from other poplar species? J Exp Bot 56:2003-2010

Janz D, Behnke K, Schnitzler J-P, Kanawati B, Schmitt-Kopplin P, Polle A (2010) Pathway analysis of the transcriptome and metabolome of salt sensitive and tolerant poplar species reveals evolutionary adaption of stress tolerance mechanisms. BMC Plant Biol 10:150

Kieffer P, Schröder P, Dommes J, Hoffmann L, Renaut J, Hausman JF (2009) Proteomic and enzymatic response of poplar to cadmium stress. J Proteomics 72:379-396

Lan T, Yang ZL, Yang X, Liu YJ, Wang XR, Zeng QY (2009) Extensive functional diversification of the Populus glutathione $S$-transferase supergene family. Plant Cell 21:3749-3766

Libault M, Wan J, Czechowski T, Udvardi M, Stacey G (2007) Identification of 118 Arabidopsis transcription factor and 30 ubiquitin-ligase genes responding to chitin, a plant-defense elicitor. Mol Plant Microb Interac 20:900-911

Markovska YK, Gorinova NI, Nedkovska MP, Miteva KM (2009) Cadmium-induced oxidative damage and antioxidant responses in Brassica juncea plants. Biol Plant 53:151-154

McCormack E, Tsai YC, Braam J (2005) Handling calcium signaling: Arabidopsis CaMs and CMLs. Trends Plant Sci 10:383-389

Milone MT, Sgherri C, Clijsters H, Navari-Izzo F (2003) Antioxidative responses of wheat treated with realistic concentration of cadmium. Environ Exp Bot 50:265-276

Nikolic N, Kojic D, Pilipovic A, Pajevic S, Kristic B, Borisev M, Orlovic S (2008) Responses of hybrid poplar to cadmium stress: photosynthetic characteristics, cadmium and proline accumulation, and antioxidant enzyme activity. Ac Biol Cracov Ser Bot 50:95-103

Olsson AS, Engstrom P, Soderman E (2004) Homeobox genes ATHB12 and ATHB7 encode potential regulators of growth in response to water deficit in Arabidopsis. Plant Mol Biol 55:663-677

Ottow EA, Brinker M, Teichmann T, Fritz E, Kaiser W, Brosché M, Kangasjärvi J, Jiang XN, Polle A (2005) Populus euphratica displays apoplastic sodium accumulation, osmotic adjustment by decreases in calcium and soluble carbohydrates, and develops leaf succulence under salt stress. Plant Physiol 139:1762-1772

Pastori GM, Foyer CH (2002) Common components, networks, and pathways of cross-tolerance to stress: the central role of "redox" and abscisic acid-mediated controls. Plant Physiol 129:460-468

Polle A, Altman A, Jiang XN (2006) Towards genetic engineering for drought tolerance in trees. In: Fladung M, Ewald D (eds) Tree transgenesis: recent developments. Springer, Berlin, pp 275-297

Rascio N, Dalla Vecchia F, La Rocca N, Barbato R, Pagliano C, Raviolo M, Gonnelli C, Gabbrielli R (2008) Metal accumulation and damage in rice ( $c v$. Vialone nano) seedlings exposed to cadmium. Environm Exp Bot 62:267-278

Robinson BH, Mills TM, Petit D, Fung LE, Green SR, Clothier BE (2000) Natural and induced cadmiumaccumulation in poplar and willow: implications for phytoremediation. Plant Soil 227:301-306

Rodriguez-Serrano M, Romero-Puertas MC, Pazmino DM, Testillano PS, Risueno MC, del Rio LA, Sandalio LM (2009) Cellular response of pea plants to cadmium toxicity: cross talk between reactive oxygen species, nitric oxide, and calcium. Plant Physiol 150:229-243

Sanita di Toppi L, Gabbrielli R (1999) Response to cadmium in higher plants. Environ Exp Bot 41:105-130

Schützendübel A, Polle A (2002) Plant responses to abiotic stresses: heavy metal-induced oxidative stress and protection by mycorrhization. J Exp Bot 53:1351-1365

Schützendübel A, Schwanz P, Teichmann T, Gross K, Langenfeld-Heyser R, Godbold DL, Polle A (2001) Cadmium-induced changes in antioxidative systems, hydrogen peroxide content, and differentiation in Scots pine roots. Plant Physiol 127:887-898

Schützendübel A, Nikolova P, Rudolf C, Polle A (2002) Cadmium and $\mathrm{H}_{2} \mathrm{O}_{2}$-induced oxidative stress in Populus $\times$ canescens roots. Plant Physiol Biochem 40:577-584

Sharma SS, Dietz KJ (2009) The relationship between metal toxicity and cellular redox imbalance. Trends Plant Sci 14:43-50

Singh SK, Kakani VG, Surabhi G-K, Reddy KR (2010) Cowpea (Vigna unguiculata [L.] Walp.) genotypes response to multiple abiotic stresses. J Photochem Photobiol B Biol 100:135-146

Sixto H, Salvia J, Barrio M, Ciria MP, Cañellas I (2011) Genetic variation and genotype-environment interactions in short rotation Populus plantations in southern Europe. New For 42:163-177

Suzuki N, Koizumi H, San N (2001) Screening of cadmium-responsive genes in Arabidopsis thaliana. Plant Cell Environ 24:1177-1188

Wójcik M, Tuikendorf A (2011) Glutathione in adaptation of Arabidopsis thaliana to cadmium stress. Biol Plant 55:125-132

Xu J, Yin H, Liu XJ, Li X (2010) Salt affects plant Cd-stress responses by modulating growth and Cd accumulation. Planta 231:449-459 